\title{
Identification of adapted varieties of groundnuts (Arachis hypogaea L.) in SEKE BANZA area, Democratic Republic of the Congo (DRC)
}

\author{
Franck NGOYI TSHITE ${ }^{1 *}$, Justin MUDIBU WA KABANGU ${ }^{2,4}$, \\ Van TSHIOMBE MULAMBA ${ }^{2,3}$ and Gabriel MASIALA MUANDA ${ }^{1}$ \\ ${ }^{I}$ INERA, Station of Gimbi, Democratic Republic of Congo. \\ ${ }^{2}$ CGEA/CREN-K, Kinshasa, Democratic Republic of Congo. \\ ${ }^{3}$ Faculty of Agronomy, University of Kinshasa, Democratic Republic of the Congo. \\ ${ }^{4}$ Faculty of Agronomy, National Pedagogic University, Kinshasa, Democratic Republic of Congo. \\ *Corresponding author, E-mail: tshitengoyi@yahoo.fr, franckngoyi_tshite1980@yahoo.fr; \\ Tel.: (+243) 815298 460, (+243) 971266447
}

\begin{abstract}
The present study aimed at identifying the most effective and adapted groundnut varieties to the climatic conditions of SEKE BANZA area, province of Bas Congo, Democratic Republic of Congo (DRC.). Twenty four varieties from IITA /DRC were tested in experimental site of INERA GIMBI. Randomised block design with four replications was used to evaluate grain yields ( $t / h a)$, height of plant at the end of flowering $(\mathrm{cm})$, number of days for plant flowering, number of maturity days, stem diameter at the first internodes (mm), Rosette incidence disease(\%), Cercospora leaf spots incidence disease (\%), Rosette severity (1-5), Cercospora severity (1-5). Compared to controls, ten varieties revealed more effective. Evaluated parameters during season A were higher than during season B. Varieties not released have to be listed on national catalogue before their popularization. In SEKE BANZA area, diseases attack level is low mostly in season A. Number of days for plant maturity was correlated to number of days of plant flowering. (c) 2015 International Formulae Group. All rights reserved.
\end{abstract}

Keywords: Arachis hypogaea L., illness, effective variety, yield.

\section{INTRODUCTION}

Groundnut (Arachis hypogaea L.) occupies the first row among alimentary leguminous seeds mostly consumed in African countries like DRC (Ndjeuma et al., 2006). It is the fifth-largest oilseed produced in the world after palm nut, soybean, rapeseed and sunflower (Karunakaran et al., 2013). It keeps its character of incoming generation culture for the producers (Nigam et al., 2004). It is a good source of protein and contributes satisfying protein requirements mainly in developing countries (Eapen S. 2003; Okello et al., 2010), and for people whose revenue is so low that it does not allow them to regularly get food from animal origin (Wudiri, 1992; Osseyi et al., 2003). To promote this crop is very important in DRC as a developing country where food needs are growing higher and higher (Dugué et al., 2004; Okello et al., 2014).

Success of a culture requires accurate identification of high yield potential cultivars, 
adapted to specific environment and to determined production systems, resistant or tolerant to environmental stress, resistant to disease and insects attacks (Hossain and Hossain, 2013). Tshilenge et al. (2012) reported that the decrease of groundnut grain yields in the world and particularly in DR Congo is attributed to foliar diseases (mean of $850 \mathrm{~kg} / \mathrm{ha}$ in DR Congo, low compared to $2500 \mathrm{~kg} / \mathrm{ha}$ in developed countries). Walliyar (1990) reported the yields losses of 50\% - 70 $\%$ were recorded in West Africa and up to $50 \%$ worldwide. In Bangladesh, groundnut can be attacked by at least 21 diseases (Talukder, 1974; Ahmed and Hossain, 1985; Ahmed et al., 1985). Among the diseases, early leaf spot caused by Cercospora arachidicola $S$. Hori and late leaf spot Cercosporidium personatum are the most important foliar diseases of the crop (Meena et al., 2014). In sub-Saharan Africa, the rosette disease is the first one which affects groundnuts culture and reduces its production (Naidu et al., 1999).

This culture requires minimum raining of $500-600 \mathrm{~mm}$ of well distributed rain (Mayeux, 2001). SEKE BANZA area which records an average of $1185.24 \mathrm{~mm}$ of rain yearly (Table 2), $88.8 \%$ of relative moisture, $28.5{ }^{\circ} \mathrm{C}$ of temperature and a productive soil, is an attractive area for groundnuts production. However, drop in yield is recorded. Peasants are not satisfied with grain yield obtained (Table 3) while using their local materials. This urges them to look for most effective materials).

The present study was undertaken to find out the most productive and adapted groundnuts varieties in SEKE-BANZA area, in order to help peasants in increasing their grain yield and their income.

\section{MATERIALS AND METHODS}

\section{Experimental site}

Investigation was conducted during two seasons: season A (from mid-September to
mid-December 2011) and season B (from mid-February to mid-May 2012), in SEKEBANZA area, in the experimental field of INERA (Institut National pour l' Etude et la Recherche Agronomiques) NGIMBI. This site is located at $5^{\circ} 28^{\prime} 531$ " western longitude and $13^{0} 22$ ' 071 " southern latitude; $339 \mathrm{~m}$ of altitude and is a dry alluvial valley. The region falls within the AW5 climate type according to Köppen classification characterized by two rainy seasons: season A (from mid-September to mid-December), season B (from midFebruary to mid-May) and two dry seasons (from mid-January to mid-February; from mid-June to mid-August) (Muderhwa, 2009). The rainfall mean is $1185.24 \mathrm{~mm} /$ year (Table 3). Experimental field is an herbal fallow. Its vegetation is the grassy savannah dominated by Imperata cylindrica. Its soil is sand-clay, black colored and enriched in humus (SENAFIC, 2011). In season $\mathrm{A}$, the site received an average of $370.2 \mathrm{~mm}$ of rain and $92.1 \%$ of relative moisture. Temperature was varying between 21.8 and $28.2^{\circ} \mathrm{C}$. During the season $\mathrm{B}$, site received an average of $349.7 \mathrm{~mm}$ of rain and $85.6 \%$ of relative moisture. Temperature was varying between 25.9 and $30.2{ }^{\circ} \mathrm{C}$.

\section{Plant materials}

Twenty two varieties of groundnuts from IITA (International institute of tropical agriculture) DRC and two local varieties as controls were tested. Table 1 presents these varieties and their respective origins.

\section{Cultural technique}

Two seeds were sown at $20 \mathrm{~cm} \mathrm{x} 40 \mathrm{~cm}$ and on a depth of about 2-3 cm. Manual weeding was carried out as to keep the field clean. The experiment was a randomized bloc design with four replicates. The plot was ploughed and ridged at a spacing of $1.5 \times 1 \mathrm{~m}$. Grass plot size (experiment unit) was $2 \mathrm{~m}$ long and $1.6 \mathrm{~m}$ wide. Trials were performed in 2011 and 2012 years. The seeds were sown in 
20 October 2011 for season $\mathrm{A}$ and on 28 March 2012 for season B.

\section{Measured traits}

Observations were made daily and data on the yield ( $t / h a)$ at the end of cultural cycle, the height of plant at the end of flowering (cm), number of maturity days at $50 \%$ of plants maturity, stem diameter $(\mathrm{mm})$ at the end of flowering, number of days of plant flowering and incidence disease (\%) were recorded and submitted to analysis of variance (ANOVA) using $\mathrm{R}$ software. Main effects were separated by least significant difference (LSD) test ranged at 5\% level. The Incidence of diseases (\%) was calculated following the formula stated below (Subrahmayam et al., 1995):

Diseaseincidence $(\%)=\frac{\text { Number ofinfectedleaves } / \text { plant }}{\text { TotalNumber of leaves } / \text { plant }} \times 100$

Twenty plants in population of 40 plants per parcel were used as sample to collect all data. The Incidence of diseases (\%) was collected as soon as manifested. Severity (1-5) was recorded on 60, 70 days after seedling and analyzed by $\chi^{2}$ test ranged on 5 $\%$ level.

The grain yield over (Table 9) of varieties (\%), compared to controls were determined by the following formula:

GrainYieldover $(\%)=\frac{\text { grainyieldofvariety } \text {-grainyieldof control }}{\text { grainyieldof fontrol }} \times 100$.

\section{RESULTS}

The mean values for plant height, stem diameter at the first internodes, number of days of plants flowering, number of days of plants maturity, and grain yields are presented in Table 4; the correlations of measured traits are presented in Table 6. The incidence of diseases is presented in table 5. Grain yields over controls are presented in Table 7.

\section{Plant height and stem diameter}

The values for stem diameter and Plant height are summarized in Table 4. Plant height is one of selection criteria in breeding. In general, season A presented higher value than season B. Maximum in season A was recorded with ICVG SM $86021(49.9 \mathrm{~cm})$ variety, followed by G17 $(47.9 \mathrm{~cm})$. Maximum in season B was achieved with MGV4 variety $(33.7 \mathrm{~cm})$ followed by ICGV SM $86021(32 \mathrm{~cm})$. The smallest values come from MGV4 (28.4) in season A and from ZUANI (19.7) in season B. Significant differences among accessions were observed ( $\mathrm{p} \geq 0.05)$. The control plant heights were 38.7 $\mathrm{cm}$ and $38.5 \mathrm{~cm}$ in season $\mathrm{A} ; 20.2 \mathrm{~cm}$ and $19.7 \mathrm{~cm}$ in season $\mathrm{B}$, respectively for MANDINGU and ZUANI.

The mean high values of Stem diameter were recorded with ICGV SM 86021 variety $(0.49 \mathrm{~cm})$ followed by ICGV SM $99594(0.47$ $\mathrm{cm})$. The smallest mean value is $0.31 \mathrm{~cm}$ with 045/04/3 variety. Significant difference was detected among accessions ( $\mathrm{p} \geq 0.05)$.

\section{Numbers of days of plant flowering and Number of days for plant maturity}

The values for Number of days of plant flowering and Number of days for plant maturity are summarized in Table 4. Differences in number of days for plants flowering among accessions were significant ( $\mathrm{p} \geq 0.05$ ). MGV4 variety got maturity in mean of 41 days after seedling, whereas the 23 other varieties took a mean of 27 days to get ripen.

As with Numbers of days of plant flowering, there were significant differences ( $p \geq 0.05$ ) among accessions for number of days for plants maturity who indicates the duration of cultural cycle. The average ranged from 84 days (018/04/ and 3045/04/3) to 122 days (MGV4). The correlation between number of days for plant maturity and number of days of plant flowering was 0.88 and highly significant. 


\section{Grain yields}

Grain yields were analyzed in details (Table 4). Considering the two seasons, maximum of grain yields was recorded with JL24 (1.329), followed by 048/04/3 (1.258) varieties. Compared to the control, grain yields $(0.903 \mathrm{t} / \mathrm{ha}$ MANDINGU and 0.998 t/ha ZUANI), 10 varieties were more efficient (JL24, A1408, 048/043/3, 064/04/2, 018/04/3, 077/04/4, 080/04/1, ICGV SM 86021, G17 and ICGV SM 95523) because their grain yields over is higher than $10 \%$ according to IITA (2012). The above varieties have produced respectively grain yields over controls of $40.15 \%, 17.80 \%, 32.28 \%, 31.09 \%$, $28.77 \%$, and $14.24 \%$ and $22.76 \%, 18.44 \%$ and $17.70 \%$; compared to MANDINGU and
ZUANI. They can be recommendable to famers. There was no correlation between grain yield per hectare and others parameters measured.

\section{Rosette and Cercospora disease}

Incidences of Rosette and Cercospora diseases were analyzed in details (Table 5). In season $\mathrm{B}$, diseases manifested particularly the rosette disease and the Cercospora leaf spot disease. Significant differences among accessions were observed in level of attack of diseases (Chi-square test). All varieties were sensitive to diseases except COMMON which was resistant to rosette disease. The ICGM SM 95523 variety is very sensitive to rosette $(6.5 \%)$ of incidence.

Table1: Origin of varieties and their botanical type.

\begin{tabular}{lcc}
\hline Varieties & Origin & Botanical varieties (types) \\
\hline A1408 & IITA/ DRC & Spanish \\
CG7 & IITA/ DRC & Valencia \\
COMMON & IITA/ DRC & Valencia \\
G17 & IITA/ DRC & Valencia \\
ICGM 281 & IITA/ DRC & Valencia \\
ICGM SM 95523 & IITA/ DRC & Valencia \\
ICGV SM 86021 & IITA/ DRC & Spanish \\
ICGV SM 95523 & IITA/ DRC & Valencia \\
ICGV SM 95530 & IITA/ DRC & Valencia \\
ICGV SM 96722 & IITA /DRC & Spanish \\
ICGV SM 99594 & IITA/ DRC & Valencia \\
JL24 & IITA /DRC & Spanish \\
JL24-1 & IITA/ DRC & Spanish \\
JL24-2 & IITA/ DRC & Spanish \\
MGV4 & IITA/ RDC & Virginia \\
$077 / 04 / 4$ & IITA/ DRC & Spanish \\
$018 / 04 / 3$ & IITA/ DRC & Spanish \\
$045 / 04 / 3$ & IITA /DRC & Spanish \\
$048 / 04 / 3$ & IITA/ DRC & Spanish \\
$064 / 04 / 2$ & IITA/ DRC & Spanish \\
$080 / 04 / 1$ & IITA/ DRC & Spanish \\
$050 / 04 / 1$ & IITA/ DRC & Spanish \\
MANDINGU & SEKE BANZA /DRC & Valencia \\
ZUANI & SEKE BANZA/DRC & Valencia \\
\hline & &
\end{tabular}


Table 2: Average of rainfall and number of rainy days in experiment site since 1977 to 2012.

\begin{tabular}{lcccc}
\hline Months & \multicolumn{2}{c}{ Average of 25 years (1977 - 2002) } & \multicolumn{2}{c}{ Average of 10 years (2002 - 2012) } \\
\cline { 2 - 5 } & $\begin{array}{c}\text { Rainfall } \\
(\mathbf{m m})\end{array}$ & Number of rainy days & $\begin{array}{c}\text { Rainfall } \\
(\mathbf{m m})\end{array}$ & $\begin{array}{c}\text { Number of rainy } \\
\text { days }\end{array}$ \\
\hline January & 119.44 & 13.96 & 145.68 & 13.1 \\
February & $14 ., 68$ & 12.46 & 122.86 & 10.3 \\
March & 161.56 & 15.5 & 167.98 & 13.9 \\
April & 169.25 & 15.22 & 175.52 & 15 \\
May & 60.06 & 11.74 & 37.84 & 10.5 \\
Jun & 1.9 & 4.74 & 3.5 & 7.1 \\
July & 1.6 & 5.13 & 1.82 & 5.4 \\
August & 3.87 & 6.09 & 5.38 & 9 \\
September & 14.9 & 15.88 & 7.76 & 12 \\
October & 61.1 & 18.42 & 81.88 & 21.8 \\
November & 185.48 & 18.79 & 245.76 & 20.33 \\
December & 142.08 & 16.17 & 189.26 & 16 \\
Total & $\mathbf{1 0 6 8 . 9 2}$ & 154.10 & $\mathbf{1 1 8 5 . 2 4}$ & 154.43 \\
Average & $\mathbf{8 9 . 0 8}$ & 12.84 & $\mathbf{9 8 . 7 7}$ & 12.87 \\
\hline
\end{tabular}

Table 3: MANDINGU and ZUANI production in SEKE-BANZA area.

\begin{tabular}{lcc}
\hline $\begin{array}{l}\text { Peasant Organizations } \\
\text { (DNGO) }\end{array}$ & $\begin{array}{c}\text { Production in season A in } \\
\mathbf{2 0 1 1}(\mathbf{t} / \mathbf{h a})\end{array}$ & $\begin{array}{c}\text { Production in season B in 2011 } \\
(\mathbf{t} / \mathbf{h a})\end{array}$ \\
\hline MDM & 0.87 & 0.86 \\
LE RURAL & 0.75 & 0.76 \\
ADEM & 0.82 & 0.80 \\
APROFEL & 0.89 & 0.87 \\
CODELU & 0.77 & 0.67 \\
LERURAL & 0.55 & 0.66 \\
GRAB & 0.88 & 0.48 \\
GRAPS & 0.91 & 0.81 \\
GPM & 0.56 & 0.84 \\
Average & 0.767 & 0.741 \\
\hline
\end{tabular}


F. NGOYI TSHITE et al. / Int. J. Biol. Chem. Sci. 9(2): 652-663, 2015

Table 4: Plants height, Stem diameter, Number of days to 50\% flowering, Number of days to maturity and Grains yield.

\begin{tabular}{|c|c|c|c|c|c|c|c|c|c|c|c|}
\hline \multirow[b]{2}{*}{ varieties } & \multicolumn{2}{|c|}{ Plants height (cm) } & \multicolumn{2}{|c|}{ Stem diameter (cm) } & \multicolumn{2}{|c|}{$\begin{array}{c}\text { Number of days to } 50 \% \\
\text { flowering }\end{array}$} & \multicolumn{2}{|c|}{$\begin{array}{c}\text { Number of days to } \\
\text { maturity }\end{array}$} & \multicolumn{2}{|c|}{ Grain yield (t/ha) } & \multirow{2}{*}{$\begin{array}{c}\text { Grain yield } \\
\text { average (t/ha) }\end{array}$} \\
\hline & A season & B season & A season & B season & A season & B season & A season & B season & A season & B season & \\
\hline A1408 & 41.6 & 26.7 & 0.45 & 0.42 & 28.7 & 28.2 & 89.7 & 90 & 1.17 & 1.054 & 1.112 \\
\hline CG7 & 42.2 & 26.1 & 0.49 & 0.46 & 26.9 & 26 & 85.5 & 85.2 & 1.125 & 0.907 & 1.016 \\
\hline COMMON & 45.4 & 25.9 & 0.55 & 0.56 & 27 & 26 & 90 & 89.2 & 0.842 & 0.718 & 0.78 \\
\hline G17 & 47.9 & 29.6 & 0.52 & 0.5 & 25.8 & 26 & 89.5 & 90 & 1.135 & 1.097 & 1.116 \\
\hline ICGM 281 & 43.7 & 25.1 & 0.54 & 0.54 & 26.7 & 26 & 89.5 & 89 & 0.93 & 0.905 & 0.917 \\
\hline ICGM SM 95523 & 47.1 & 27.4 & 0.52 & 0.5 & 29 & 26.7 & 89 & 88 & 1.065 & 0.878 & 0.971 \\
\hline ICGV SM 86021 & 49.9 & 32 & 0.59 & 0.59 & 28.7 & 29 & 90 & 89.2 & 1.26 & 0.987 & 1.123 \\
\hline ICGV SM 95523 & 46.1 & 30.3 & 0.51 & 0.5 & 27.5 & 28.7 & 89 & 89.7 & 1.285 & 1.014 & 1.149 \\
\hline ICGV SM 95530 & 42.8 & 26 & 0.56 & 0.55 & 28.5 & 27.5 & 89.5 & 89.5 & 1.057 & 0.845 & 0.951 \\
\hline ICVG SM 96722 & 39.9 & 20.3 & 0.47 & 0.46 & 26.2 & 28.5 & 89.2 & 89 & 1.022 & 1.054 & 1.038 \\
\hline ICGV SM 99594 & 40.5 & 24.8 & 0.57 & 0.57 & 27.7 & 26.2 & $90, .2$ & 89 & 1.127 & 0.793 & 0.96 \\
\hline JL24 & 40 & 27.3 & 0.44 & 0.43 & 29 & 27.7 & 87.5 & 88.7 & 1.54 & 1.119 & 1.329 \\
\hline JL24-1 & 38.8 & 21.5 & 0.42 & 0.43 & 29.5 & 29 & 88 & 89.2 & 1.137 & 0.816 & 0.976 \\
\hline JL24-2 & 39,2 & 27.8 & 0.43 & 0.42 & 29 & 29,5 & 88,5 & 88,2 & 1.122 & 0.787 & 0.954 \\
\hline MGV4 & 28.4 & 33.7 & 0.46 & 0.44 & 42.2 & 40.2 & 121.2 & 122 & 1.2 & 0.63 & 0.915 \\
\hline $077 / 04 / 4$ & 35.4 & 23.4 & 0.48 & 0.45 & 30 & 29 & 85.1 & 85.2 & 1.427 & 1.178 & 1.178 \\
\hline $018 / 04 / 3$ & 38.6 & 20.8 & 0.47 & 0.47 & 26.3 & 27 & 84 & 85.2 & 1.252 & 1.19 & 1.221 \\
\hline $045 / 04 / 3$ & 37.6 & 21.5 & 0.51 & 0.52 & 28.2 & 27.2 & 85.7 & 84 & 1.215 & 0.905 & 1.06 \\
\hline $048 / 04 / 3$ & 34.2 & 25.2 & 0.46 & 0.43 & 28.7 & 27.7 & 86.7 & 86.7 & 1.462 & 1.054 & 1.258 \\
\hline $064 / 04 / 2$ & 38.4 & 22.5 & 0.47 & 0.45 & 27 & 27 & 86.2 & 86.5 & 1.38 & 1.107 & 1.243 \\
\hline 080/04/1 & 34.7 & 24.7 & 0.44 & 0.45 & 29 & 29 & 85.2 & 85.7 & 1.657 & 0.671 & 1.164 \\
\hline $050 / 04 / 1$ & 32.3 & 20.4 & 0.48 & 0.45 & 25.5 & 25.4 & 85.2 & 85.5 & 0.94 & 0.832 & 0.886 \\
\hline MANDINGU & 38.7 & 20.2 & 0.47 & 0.47 & 24.5 & 24.5 & 85.7 & 87 & 0.97 & 0.837 & 0.903 \\
\hline ZUANI & 38.5 & 19.7 & 0.49 & 0.48 & 28.5 & 28.6 & 89.2 & 89.5 & 1.077 & 0.919 & 0.998 \\
\hline $\mathrm{LSD}_{0.05}$ & 2.3 & 1.6 & 0.9 & 0.7 & 0.6 & 0.4 & 0.4 & 0.8 & 0.11 & 0.09 & 0.1 \\
\hline
\end{tabular}


Table 5: Rosette incidence and Cercospora leaf spots incidence.

\begin{tabular}{lcc}
\hline Varieties & Rosette incidence (\%) & Cercospora leaf spots incidence (\%) \\
\hline $018 / 04 / 3$ & 2.5 & 3.5 \\
$045 / 04 / 3$ & 2.75 & 1.775 \\
$048 / 04 / 3$ & 1.5 & 3.125 \\
$050 / 04 / 1$ & 2.25 & 2.75 \\
$064 / 04 / 2$ & 1.75 & 4.5 \\
$077 / 04 / 4$ & 1.5 & 6 \\
$080 / 04 / 1$ & 3.1 & 1.35 \\
A1408 & 3.375 & 1.65 \\
CG7 & 3.65 & 1.525 \\
COMMON & 0 & 2.35 \\
G17 & 1.575 & 2.225 \\
ICGM281 & 4.6 & 2.1 \\
ICGM-SM-95523 & 6.5 & 1.6 \\
ICGV-SM-86021 & 1.95 & 3.25 \\
ICGV-SM-95523 & 1.925 & 3.05 \\
ICGV-SM-95530 & 1.5 & 3.35 \\
ICGV-SM-96772 & 3 & 7.9 \\
ICGV-SM-99594 & 3.35 & 2.65 \\
JL24 & 3.25 & 2.425 \\
JL24-1 & 1.25 & 2.3 \\
JL24-2 & 2 & 3.175 \\
MANDINGU & 3.25 & 1.625 \\
MGV4 & 3.25 & 3.5 \\
ZUAINI & 2 & 2.2 \\
LSD 0.05 & 0.4 & 0.8 \\
\hline 1: no symptom; 2: less than a half leave stunted; 3: up to a half of leave stunted; $4:$ yellowing and leaves drying; \\
5: plant death . & & \\
& &
\end{tabular}

Table 6: Pearson's correlations among some morphological and agronomic traits of groundnuts.

\begin{tabular}{lcccccc}
\hline & Variety & Plant height & $\begin{array}{c}\text { Stem } \\
\text { diameter }\end{array}$ & flowering & maturity & $\begin{array}{c}\text { Grain } \\
\text { yield }\end{array}$ \\
\hline Variety & 1 & & & & & \\
Plant height & $-0,32$ & 1 & & & & \\
Stem diameter & $-0,39$ & 0,31 & 1 & & & \\
Flowering & 0,07 & 0,02 & $-0,22$ & 1 & & \\
Maturity & $-0,08$ & 0,03 & $-0,05$ & 0,88 & 1 & \\
Grain yield & 0,11 & 0,41 & $-0,16$ & 0,05 & $-0,19$ & 1 \\
\hline
\end{tabular}


Table 7: The yield over controls of tested varieties.

\begin{tabular}{|c|c|c|c|c|}
\hline varieties & $\begin{array}{c}\text { Grain Yield } \\
\text { (average of two } \\
\text { seasons) }(\mathrm{t} / \mathrm{ha})\end{array}$ & $\begin{array}{l}\text { Grain Yield } \\
\text { over } \\
\text { MANDINGU (\%) }\end{array}$ & $\begin{array}{l}\text { Grain yield } \\
\text { over } \\
\text { ZUANI (\%) }\end{array}$ & $\begin{array}{c}\text { Average } \\
\text { grain yield } \\
\text { over }(\%)\end{array}$ \\
\hline A1408 & 1.112 & 23.14 & 11.42 & 17.28 \\
\hline CG7 & 1.016 & 12.30 & 2.00 & $\begin{array}{c}\text { Less than } \\
10 \%\end{array}$ \\
\hline COMMON & 0.780 & -13.8 & -2.00 & $\begin{array}{c}\text { Less than } \\
10 \%\end{array}$ \\
\hline G17 & 1.116 & 23.58 & 11.82 & 17.70 \\
\hline ICGM281 & 0.917 & 1.55 & -8.11 & $\begin{array}{c}\text { Less than } \\
10 \%\end{array}$ \\
\hline ICGM SM 95523 & 0.971 & 7.50 & -2.70 & $\begin{array}{c}\text { Less than } \\
10 \%\end{array}$ \\
\hline ICGV SM 86021 & 1.123 & 24.36 & 12.52 & 18.44 \\
\hline ICGV SM 95523 & 1.149 & 27.24 & 15.13 & 21.18 \\
\hline ICGV SM 95530 & 0.951 & 5.31 & -4.70 & $\begin{array}{c}\text { Less than } \\
10 \%\end{array}$ \\
\hline ICGV SM 96722 & 1.038 & 14.95 & 4.00 & $\begin{array}{c}\text { Less than } \\
10 \%\end{array}$ \\
\hline ICGV SM 99594 & 0.960 & 6.31 & -3.80 & $\begin{array}{c}\text { Less than } \\
10 \%\end{array}$ \\
\hline JL24 & 1.329 & 47.15 & 33.16 & 40.15 \\
\hline JL24-1 & 0.976 & 8.00 & -2.20 & $\begin{array}{c}\text { Less than } \\
10 \%\end{array}$ \\
\hline JL24-2 & 0.954 & 5.64 & -4.40 & $\begin{array}{c}\text { Less than } \\
10 \%\end{array}$ \\
\hline MGV4 & 0.915 & 1.32 & -8.30 & $\begin{array}{c}\text { Less than } \\
10 \%\end{array}$ \\
\hline 077/04/4 & 1.178 & 30.45 & 18.03 & 24.24 \\
\hline $018 / 04 / 3$ & 1.221 & 35.21 & 22.34 & 28.77 \\
\hline $045 / 04 / 3$ & 1.060 & 17.38 & 6.21 & $\begin{array}{c}\text { Less than } \\
10 \%\end{array}$ \\
\hline $048 / 04 / 3$ & 1.258 & 39.31 & 26.05 & 32.28 \\
\hline $064 / 04 / 2$ & 1.243 & 37.65 & 24.54 & 31.09 \\
\hline 080/04/1 & 1.164 & 28.90 & 16.63 & 22.76 \\
\hline 050/04/1 & 0.886 & -1.88 & -11.22 & $\begin{array}{c}\text { Less than } \\
10 \%\end{array}$ \\
\hline MANDINGU(check1) & 0.903 & 0 & - & - \\
\hline ZUANI(check2) & 0.998 & - & 0 & - \\
\hline
\end{tabular}

\section{DISCUSSION}

This evaluation is important for breeding programs. Identification of adapted varieties of groundnuts in SEKE-BANZA area was the objective of this study. Their use is one of the most effective ways to improve production (Nigam et al., 2004). There were significant differences among accessions for evaluated parameters. 


\section{Plant height}

Plant height at maturity is an important characteristic in cultivar evaluation. Mean values for plant height at maturity varies from $28.4 \mathrm{~cm}$ to $49.9 \mathrm{~cm}$ in Season A and from 19.7 $\mathrm{cm}$ to $33.7 \mathrm{~cm}$ in season B. Bangata et al. (2013) reported low mean plant height in the condition of KINSHASA with the same varieties. Maximum: $17.8 \mathrm{~cm}$ with ICGV SM 95530 variety and ICGV SM 95523 variety; minimum: $12.8 \mathrm{~cm}$ with ICGV SM 281 variety. The richness of soil in humus should be responsible of this situation. Hossain and Hossain (2013) reported a mean plant height of $44.4 \mathrm{~cm}$ with Dhaka-1 variety in BANGLADESH conditions. Growth behaviour of a plant mainly depends on its genetic constitution and prevailing environment conditions (Meena and Yadav. 2014). In general, season A presented higher value than season B. During the test period, quantity of rainfall in season A higher than in season $\mathrm{B}$, and their equitable distribution.

\section{Stem diameter}

The stem diameter of plants indicates the capacity of plants to support the weight of production. The mean high values were recorded with ICGV SM 86021 variety $(0.49 \mathrm{~cm})$ followed by ICGV SM $99594(0.47$ $\mathrm{cm})$. Bangata et al. (2013) reported low values of stem diameter in the conditions of KINSHASA with the same varieties. According to these authors, poverty of the soil of KINSHASA and its sandy texture are responsible of the reduction of stem diameter. The sand-clay texture soil of INERA GIMBI, its richness in humus (SENAFIC. 2011), would favour development of size of stem diameter in this study.

\section{Numbers of days of plant flowering}

Differences in number of days for plants flowering among varieties were significant. Ndoye and Smith (1992) in Texas reported that days of plant flowering vary between 34 to 38 days after seedling. Kumar and Abbo (2000) assessed several genotypes in India and reported that the area location influences the beginning of plants flowering (95.6 days in Hisan $29^{\circ} \mathrm{N}, 75.5$ days at Gwalior $26^{\circ} \mathrm{N}$ and 51.3 days at patancheru $18^{\circ} \mathrm{N}$ ) and number days of plant flowering.

\section{Number of days for plant maturity}

Significant differences were observed $(p \geq 0.05)$ among accessions for number of days for plants maturity who indicates the duration of cultural cycle. The correlation between number of days for plant maturity and number of days of plant flowering was 0.88 and highly significant. With Dhaka-1 variety, Hossain and Hossain (2013) reported high mean value (167 days to get maturity) in Bangladesh conditions. Nobody (2004) classified groundnuts in 4 groups: the very early, the early, the later and the oil one. It means varieties that get ripen respectively at less than 100 days, at 105 days, at 122 days and at 126 days after seedling. Comparing ours results to the above classification, MGV4 variety would be oil. According to Khalfaoui (1999), 90 days after seedling at $75 \%$ of groundnuts in maturity is one of the criterions of precocity. Thus, all our varieties are early, except MGV4. For this author, cultivars with a cycle varying between 75 and 95 days after seedling are early, type Spanish and Valencia; varying from 95 to 100 , are half-early type Virginia; 120-150 days, are later. Compared to the above author classification, Twentythree varieties in this investigation are early; only one is later (the MGV4 variety).

\section{Grain yields}

The evaluation of agronomic traits is important for breeding program particularly groundnut varieties are adapted to the specific agro-ecological regions and the phenotypes are highly influenced by environmental 
factors (Li and Nelson. 2001). Compared to the control, grain yields $(0.903 \mathrm{t} / \mathrm{ha}$ MANDINGU and $0.998 \mathrm{t} / \mathrm{ha}$ ZUANI), the result of present study show that 10 varieties were more efficient (JL24, A1408, 048/043/3, 064/04/2, 018/04/3, 077/04/4, 080/04/1, ICGV SM 86021, G17 and ICGV SM 95523) because their grain yields over is higher than 10\% according IITA (2012). The above varieties have produced respectively grain yields over controls of $40.15 \%, 17.80 \%$, $32.28 \%, 31.09 \%, 28.77 \%$, and $14.24 \%$ and $22.76 \%, 18.44 \%$ and $17.70 \%$; compared to MANDINGU and ZUANI (Table5). They can be recommendable to famers. The level of grain yields depends probably on the specific environment. Naidu et al. (1999) reported lower grain yield in Malawi with the same varieties. For example, JL24 produced $1.329 \mathrm{t} /$ ha at Gimbi and $0.34 \mathrm{t} /$ ha in Malawi; the CG7 variety produced $1.016 \mathrm{t} / \mathrm{ha}$ in Gimbi whereas in Chitedze it produced only $0.23 \mathrm{t} /$ ha. With the same varieties, Bangata et al. (2013) reported high grain yield in the condition of Kinshasa. JL24 produced 2.9t/ha in Kinshasa, G17 produced $1.5 \mathrm{t} / \mathrm{ha}$ in Kinshasa whereas 1.016 t/ha at Gimbi, ICGV SM 96722 produced $1.5 \mathrm{t} / \mathrm{ha}$ in Kinshasa whereas 1.036 t/ha at Gimbi. Jan de Graaff et al. (2011) reported also high grain yields: 12.5 t/ha, $9.2 \mathrm{t} / \mathrm{ha}$ and $6.8 \mathrm{t} / \mathrm{ha}$ respectively for JL24, G17 and A1408 in different countries of Sub- Saharan Africa.

\section{Rosette and Cercospora disease}

All varieties were sensitive to diseases except COMMON which was resistant to rosette disease. The ICGM SM 95523 variety is very sensitive to rosette $(6.5 \%)$ of incidence. Naidu et al. (1999) reported that incidence of rosette varies from $4 \%$ to $67 \%$. JL24 variety was attacked at 67\%, CG7 was attached at $53 \%$ at Chitedze in Malawi. But less than the above values in this study $(3.65$ and 3.25) respectively for CG7 and JL24 were recorded. Natarajan and Sachithanantham (1986) reported that Cercospora leaf spot disease can cause losses of grain yield in order of $35 \%$ until $80 \%$. Tshilenge et al. (2011) showed that the attack level of Cercospora depends on varieties. These authors indicated high incidence (beyond 80\%) with 9 among 24 varieties used in the conditions of Mont Amba in Kinshasa. Tshilenge et al. (2012) reported that JL24, ICG9998, ICGM 281, A65, A1408 and G17 varieties are more sensitive to Cercospora leaf spot in conditions of Ngandajika, on scale varying from (1-9) . The high sensitive varieties on Cercospora leaf spots were 077/04/4 and ICGM SM 96772 , respectively $(6 \%$ and $7.9 \%)$ of incidence. The sensitivity should depend on each variety and each environment. Results on diseases revealed the sensibility of varieties on Cercospora and rosette, but the level was low, less than $10 \%$. COMMON variety was resistant to rosette disease. Genetic constitution of each variety and the ecoclimatic conditions would influence the development of growth parameters ( $\mathrm{Li} \mathrm{Z}$ and Nelson R. 2001; Hossain and Hossain. 2013).

\section{ACKNOWLEDGEMENTS}

We are grateful to PANA-ASA project to have financed the present study.

\section{REFERENCES}

Ahmed HU, Hossain MM.1985. Crop disease survey and establishment of a herbarium at BARI. Final Report, Plant Pathol. Div., BARI. Joydebpur, Gazipur, P. 107.

Bangata BM, Ngbolua KN, Mawa M, Minengu M, Mobambo KN. 2013. Etude comparative de la nodulation et $\mathrm{du}$ rendement de quelques variétés d'arachide (Arachis hypogaea L., Fabaceae) cultivées en conditions écoclimatiques de Kinshasa, République 
Démocratique du Congo, Int. J. Biol. Chem. Sci., 7(3): 1034-1040.

Dugué P, Vall E, Lecomte P, Klein HD, Rollin D. 2004. Evolution des relations entre l'agriculture et l'élevage dans les savanes d'Afrique de l'Ouest et du Centre. Oléagineux, 11(4): 268-276.

Eapen S. 2003. Regeneration and genetic transformation in peanut: Current status and future prospect. In Applied Genetic Leguminous Biotechnology, Jaiwal PK, Singh RP (eds). Kluwar Academic publisher: Netherlands; 165-186.

Hossain MH, Hossain I. 2013. Screening of different plant extracts against spot (Cercospora arachidicola and Cercosporidium personatum) of groundnuts (Arachis hypogaea L.), Bangladesh J. Agril., Res., 38(3): 491503.

IITA. 2012. Integration of climate changes in selection, maintenance of varieties and the production of basic seeds. Environment Ministry, nature protection and tourism.

Jan de Graaff, Kessler A, Jan Willem N. 2011. Agriculture and food security in selected countries in Sub-Saharan Africa: diversity in trends and opportunities. Food Security, 3(2): 195213.

Khalfaoui JL.1990.Etude des composantes dela précocité chez l'arachide, Oléagineux, 45(2): 81-87.

Karunakaran KR, Gracy CP, Lokesha H, Bantilan C, Kumara Charyulu D, Parthasarathy Rao P, Nageswara Rao GD, Vaithiyalingan M, Nadaf HL, Venkataramana P, Upadhyaya HD, Janila P, KPC Rao. 2013. Groundnut Baseline and Early-Adoption Surveys in South Asia. Insights from TL-II (Phase-1) project. Research report (20), Patancheru 502 324, Andhra Pradesh,
ICRISAT program markets, Institutions and policies, India,9p.

Kumar J, Abbo S. 2000. Genetics of flowering times in Chickpea and its bearing on productivity in semiarid environments. Advances in Agronomy, Academic Press: New York; 72:

Li Z, Nelson R. 2001. Genetic diversity among soybean accessions from three countries measured by RAPDs. Crop Sci., 41: 1337-1347.

Mayeux AH. 2001: Technical document of groundnut seeds production, packaging and distribution standard in peasant area. Workshop of exchange and training, Groundnut Germoplasm Project, France.

Meena RS, Yadav RS, Meena VS. 2014. Response of groundnut (Arachis hypogaea L.) varieties to sowing dates and NP fertilizers under western dry zone of India. Bangladesh. Journal of Botany, 43(2): 169-173.

Meena RS, Yadav RS. 2014. Phenological performance of groundnut varieties under sowing environments in hyper arid zone of Rajasthan, India. Journal of Applied and Natural Science, 6(2): 344-348.

Muderhwa M. 2009. Import of soil cover in the restoration of forest ecosystems: the Luki Biosphere Reserve, Bas Congo province. TFC Graduate Agronomist degree, University of Kinshasa, p6, unpublished.

Naidu RA, Kimmins FM, Deom CM, Subrahmanyam P, Chiyembekeza, Van der Merwe.1999. Groundnut rosette, a virus Diseases affecting groundnut production in Sub-Saharan Africa. Plant Diseases, 83(8): 700 - 709.

Natarajan, Sachithanantham. 1986. Combined efficacy of fungicides on the control of late leaf spot and rust disease in 
groundnut (Arachis hypogaea L.). Oleaginous, 41(5): 231 - 233.

Ndjeuma J, Ntare BR, Waliyar F, Ramouch M. 2006. Groundnut seeds systems in West Africa. CFC Technical Paper $\mathrm{N}^{0}$ 40. International Crops Research Institute for the Semi-Arid Tropics, India.

Ndoye O, Smith OD. 1992. Flowering pattern and fruiting characteristics of five short growth duration peanut lines (1). Oléagineux, 47(5): 235-240.

Nigam SN, Giri DY, Reddy AGS. 2004. Groundnut Seed Production Manuel. Patancheru 502 324, Andhra Pradesh. International Crop Research Institution for the Semi-Arid Tropics, India.

Okello DK, Biruma M, Deom CM. 2010. Overview of groundnuts research in Uganda: Past, present and future. African J. Biotechnol., 9(39): 64486459.

Okelo DK, Tukamuhabwa P, Odong TL, Ochwo-Ssemakula M, Adriko J, Deom CM. 2014. Groundnut rosette disease symptoms types' distribution and management of the disease in Uganda. African Journal of Plant Science, 8(3): 153-163.

Osseyi LSG, Lamboni C, Lawson L. 2003. Conception of chips rich in protein based on corn and leguminous, $2^{\text {and }}$ international workshop, Ouagadougou du 23 au 28/2003.

SENAFIC. 2011. Characterization studies of tested site of PANA-ASA project/INERA GIMBI/ BAS CONGO/ KINSHSASA GOMBE.

Subrahmanyam P, McDouald D, Walliyar F, Raddy LJ, Subba Rao PV. 1995.
Screening methods and sources of resistance to rust and late leaf spot of groundnut. Information Bull. 47. ICRISAT: Patencheru, India; 20p.

Talukder MJ. 1974. Plants diseases of Bangladesh. Bangladesh J. Agric. Res., 1: 61-86.

Tshilenge-Lukanda L, Kalonji-Mbuyi A, Funny-Biola C, TshiyoyiMpunga A. 2011. Field resistance of nine groundnut (Arachis hypogea L.) varieties to Cercospora leaf spot diseases in Mont-Amba. International Journal of Research in Plant Science, 1(2): $23-28$.

Tshilenge-Lukanda L, Nkongolo KKC, Kalonji-Mbuyi A, Kizungu RV. 2012. Epidemiology of groundnut (Arachis hypogea L.) leaf spot disease: Genetic Analysis and Developmental cycles. American Journal of Plant Sciences, 1(3): $582-588$.

Walliyar F. 1990. Evaluation of Yield Losses Due to Ground-nut Leaf Diseases in West Africa, Summary Proceedings of the Second ICRISAT Regional Groundnut Meeting for West Africa, Niamey, 11-14 September 1990.

Wudiri BB, FatobaI O. 1992.Cereals in the food economy of Nigeria. In Proc. of Workshop on Recent Dev. in Cereal Prod. in Nigeria, Kaduna 2-4 Sept. 1991, Organized by IITA, Ibadan, Nigeria. 